\title{
The levels of clarithromycin and its 14-hydroxy metabolite in the lung
}

\author{
D. Honeybourne*, F. Kees**, J.M. Andrews+, D. Baldwin*, R. Wise+
}

The levels of clarithromycin and its 14-hydroxy metabolite in the lung. D. Honeybourne, F. Kees, J.M. Andrews, D. Baldwin, R. Wise. CERS Journals Ltd 1994.

ABSTRACT: Clarithromycin is a new macrolide that has a longer half-life than erythromycin and is claimed to reach higher tissue concentrations. We aimed to investigate whether, following oral administration, the drug and its 14-hydroxy metabolite reach levels in lung tissue that are likely to be clinically effective against common respiratory pathogens.

Ten patients undergoing diagnostic bronchoscopy received seven doses of clarithromycin, $500 \mathrm{mg}$ b.i.d. orally. Bronchoscopy was performed at a mean time of 4.25 $\mathrm{h}$ after the last dose. At bronchoscopy, bronchial biopsies and bronchoalveolar lavage were performed. Clarithromycin and its 14-OH metabolite were measured in serum, bronchial biopsies, epithelial lining fluid (ELF) and alveolar cells.

Mean levels of clarithromycin were $4.0 \mathrm{mg} \cdot l^{-1}$ in serum, $16.8 \mathrm{mg} \cdot \mathrm{kg}$ in bronchial biopsies, $20.5 \mathrm{mg} \cdot l^{-1}$ in ELF and $372.7 \mathrm{mg} \cdot l^{-1}$ in alveolar cells. The equivalent levels of 14-OH metabolite were $0.7,2.7,1.9$ and $38.6 \mathrm{mg} \cdot l^{-1}$, respectively.

We conclude that there is considerable concentration of clarithromycin and its 14-OH metabolite in alveolar cells, and to a lesser extent in bronchial tissue and ELF; this implies efficacy against susceptible organisms at these sites.

Eur Respir J., 1994, 7, 1275-1280.
Depts of *Thoracic Medicine, and +Medical Microbiology, Dudley Road Hospital, Birmingham, UK. **Dept of Pharmacology, University of Regensburg, Regensburg, Germany.

\section{Correspondence: D. Honeybourne}

Dept of Thoracic Medicine

Dudley Road Hospital

Birmingham B18 7QH UK.

Keywords: Bronchial mucosa

clarithromycin

epithelial lining fluid

macrophages

Received: April 41993

Accepted after revision January 261994
The efficacy of erythromycin has been limited by poor gastrointestinal absorption and gastrointestinal sideeffects. In addition, marginal activity against Haemophilus influenzae limits the use of erythromycin alone in lower respiratory tract infection.

Clarithromycin is the 6-0-methyl derivative of erythromycin. Unlike erythromycin, acid catalysed cyclization to specific anhydro-hemiketal and spiroketal derivatives does not occur; therefore, clarithromycin has much greater acid stability than erythromycin [1]. In humans, clarithromycin has at least four active metabolites, the most active being the 14-hydroxy compound. This is in marked contrast to some animal models, e.g. mice, which do not produce 14-hydroxy metabolites [2]. There is some evidence to suggest a possible synergy between clarithromycin and its 14-hydroxy metabolite, which may be of relevance for some infections [3]. Clarithromycin serum half-life is longer than erythromycin, and some studies have suggested tissue concentrations to be higher after oral clarithromycin than after oral erythromycin [4]. Macrolides are known to accumulate within cells, including neutrophils and macrophages [5].

This study was designed to look at the potential accumulation of clarithromycin and its 14-hydroxy metabolite in human bronchial mucosa, and by performing bronchoalveolar lavage (BAL) to measure the content in epithelial lining fluid and alveolar cells. Epithelial lining fluid is that fluid which lines the airspace distal to the point of wedge of the bronchoscope, and is recovered by BAL. Clarithromycin has a wide range of activity against many respiratory pathogens, and this study investigates whether the drug and its 14-hydroxy metabolite reach levels in lung tissue that are likely to be clinically effective against these respiratory pathogens.

\section{Patients and Methods}

\section{Patients}

Ten patients (9 male) who were undergoing fibreoptic bronchoscopy for diagnostic purposes were administered oral clarithromycin, $500 \mathrm{mg}$ b.i.d., for three days and then a single dose of $500 \mathrm{mg}$ on the morning of bronchoscopy. This last dose was administered between $2.5-5.5 \mathrm{~h}$ before bronchoscopy. Subjects had a mean age of 65 yrs (range 37-78 yrs). The underlying diagnoses were carcinoma of the lung in seven patients, haemoptyses of unknown cause in two patients and focal fibrosis in one patient. Exclusion criteria were the presence of active pulmonary infection, a history of allergy to macrolides, administration of antimicrobial agents in the previous two weeks, significant hepatic or renal impairment, and women of child-bearing potential. Subjects were also excluded if they were taking medications known to interact with macrolides. All subjects gave informed written consent and the study was approved by the hospital Ethics Committee. 


\section{Methods}

Bronchoscopy was performed after premedication with atropine, $0.6 \mathrm{mg}$ i.m., nebulized $4 \%$ lignocaine, 160 $\mathrm{mg}$, and midazolam, 2-7 mg i.v., just prior to bronchoscopy. After a careful examination of the airways, a standard BAL was performed using isotonic saline (divided into four $50 \mathrm{ml}$ aliquots), with gentle aspiration following instillation of each of the aliquots. Lavage was performed in the right middle lobe, or if this area had a macroscopically abnormal appearance or was abnormal on chest X-ray then the lingula was used. The fluid recovered from the first $50 \mathrm{ml}$ was discarded in order to avoid contamination with proximal airway cells and secretions. The maximum time taken for complete lavage was $3 \mathrm{~min}$. Bronchial biopsies were taken from macroscopically normal subcarinae, and a blood sample was then taken for determination of the simultaneous serum level of antibiotic.

\section{Laboratory procedures}

The lavage aspirate was immediately centrifuged at $400 \times \mathrm{g}$ for $5 \mathrm{~min}$, after a small aliquot had been removed for total cell counts. Immediate centrifugation was necessary to minimize any diffusion of antibiotic from the alveolar cells into the lavage fluid. The lavage aspirate was only processed if the differential cell count contained at least $90 \%$ macrophages. To avoid cell loss due to adherence to surfaces, Teflon containers and siliconized glassware were used. The urea content of the supernatant was measured with a modified Sigma diagnostic kit (Sigma Chemicals, Poole, UK). The blood urea concentration was measured from the blood sample taken at bronchoscopy. Antibiotic concentration in the epithelial (alveolar) lining fluid was calculated using the urea dilution method [6]:

$$
\text { ELF antibiotic concentration }=\frac{\text { ACL X UB }}{U L}
$$

where $\mathrm{UL}=$ urea concentration in the lavage; $\mathrm{UB}=$ urea concentration of blood, and ACL=antibiotic concentration in the lavage.

Alveolar macrophage cell volume was measured using velocity gradient centrifugation [7]. The mean cell volume was $2.48 \mu \mathrm{l} \cdot 10^{-6}$ cells (SEM 0.52 ).

The lavage supernatant was freeze-dried and then resuspended in distilled water to yield a ten-fold concentration. This, together with the cell pellet containing predominantly alveolar macrophages, was frozen at $-70^{\circ} \mathrm{C}$. Bronchial biopsies were collected in a humidity chamber and any blood-stained samples were discarded. After weighing, the samples were stored at $-70^{\circ} \mathrm{C}$ before assay. An improved Neubauer haemocytometer was used to measure the total white cell count. Assay of the clarithromycin and 14-hydroxy metabolite was performed on serum, lavage supernatant, alveolar macrophages and bronchial mucosa tissue, by high performance liquid chromatography (HPLC).
HPLC analysis used a pump LKB 2248 with pulse dampener (Pharmacia, Freiburg, Germany), auto-sampler SIL-9A (Shimadzu Europe, Duisburg, Germany), column heater TCM $100\left(30^{\circ} \mathrm{C}\right.$, Millipore-Waters Chromatography, Eschborn, Germany), electrochemical detector (ESA Inc., Bedford, MA, USA) and integrator C-R4A (Shimadzu Europe, Duisburg, Germany). Separation was achieved using a Zorbax SB-CN column. The mobile phase consisted of $450 \mathrm{ml}$ of $50 \mathrm{mM}$ sodium dihydrogen phosphate, $300 \mathrm{ml}$ acetonitrile and $50 \mathrm{ml}$ methanol, adjusted to $\mathrm{pH} 7.3$ with $10 \mathrm{~N}$ sodium hydroxide. Using a flow rate of $1 \mathrm{ml} \cdot \mathrm{min}^{-1}$, the retention times of the analyses were $7.7 \mathrm{~min}(\mathrm{ClaOH})$, $13.1 \mathrm{~min}$ (Clari) and $14.7 \mathrm{~min}$ (roxithromycin internal standard)

To $500 \mu \mathrm{l}$ serum were added: $100 \mu \mathrm{l}$ water (standard: $100 \mu \mathrm{l}$ water containing $1 \mu \mathrm{g}$ Clari and $0.5 \mu \mathrm{g} \mathrm{ClaOH})$, and $100 \mu \mathrm{l}$ internal standard solution $\left(10 \mu \mathrm{g} \cdot \mathrm{ml}^{-1}\right.$ roxithromycin in water). The sample was mixed and then deproteinized by addition of $500 \mu \mathrm{l}$ acetonitrile. Mixing was followed by $20 \mathrm{~min}$ incubation at $4^{\circ} \mathrm{C}$ and centrifugation. The supernatant was diluted with $1 \mathrm{ml}$ water and transferred into a disposable column (Adsorbex, filled with 100 mg C18 silicagel, Merck Co.; Darmstadt, Germany), which had been equilibrated with $5 \mathrm{ml}$ of methanol followed by $2 \mathrm{ml}$ of $50 \mathrm{MM}$ sodium phosphate buffer $(\mathrm{pH}=6.3)$. After the supernatant had passed through the extraction column, it was washed twice with $2.5 \mathrm{ml}$ of $50 \mathrm{MM}$ sodium phosphate buffer $(\mathrm{pH}=$ 6.3). The compounds of interest were eluted with $1 \mathrm{ml}$ methanol, which was subsequently diluted with $1 \mathrm{ml}$ of water, and then $50 \mu \mathrm{l}$ was injected into the analytical column.

Bronchial biopsies (4-9 mg) were homogenized in a Weaton micro-homogenizer with 20 volumes of $50 \mathrm{MM}$ sodium phosphate buffer, $\mathrm{pH}=7.0$, containing $100 \mathrm{ng} \cdot \mathrm{ml}^{-1}$ roxithromycin (internal standard). For protein precipitation, an equal volume of acetonitrile was added. After incubation at $4{ }^{\circ} \mathrm{C}(15 \mathrm{~min})$ and centrifugation $(2 \mathrm{~min}$ at $10,500 \times \mathrm{g}), 25 \mu \mathrm{l}$ supernatant were injected onto the analytical column.

The alveolar cell suspension was diluted with water to a final volume of $1,000 \mu \mathrm{l}$, ultrasonicated on ice for $1 \mathrm{~min}$ at $70 \%$ duty cycle (Branson Sonifier with microtip), and centrifuged. Five hundred microlitres supernatant was further treated as for the serum.

Lavage fluid $(5 \mathrm{ml})$ was spiked with $100 \mu \mathrm{l}$ internal standard (10 $\mu \mathrm{g} \cdot \mathrm{ml}^{-1}$ aqueous roxithromycin solution) and pipetted into a disposable column (Adsorbex (R) filled with $100 \mathrm{mg} \mathrm{C.18}$ silicagel). Further treatment was as for serum samples.

A problem arose from high lignocaine concentrations in bronchial lavage (up to $50 \mu \mathrm{g} \cdot \mathrm{ml}^{-1}$ ), which, because of similar retention characteristics, could interfere with quantification of $\mathrm{ClaOH}$, and which poisoned the detector cell (reducing the response of the detector). Better separation of lignocaine from $\mathrm{ClaOH}$ was achieved by increasing the $\mathrm{pH}$ to $7.5-7.6$ (ligno $=5.8 \mathrm{~min} ; \mathrm{ClaOH}=9.3$ $\mathrm{min}$; Clari=16.1 min; Roxi=18.8 min). The detector response recovered with time after prolonged washing with methanol. 
Table 1. - Site concentrations of clarithromycin and its 14-hydroxy metabolite

\begin{tabular}{|c|c|c|c|c|c|c|c|c|c|}
\hline $\begin{array}{l}\mathrm{Pt} \\
\text { No. }\end{array}$ & $\begin{array}{l}\text { Time after } \\
\text { dose } \\
\text { h }\end{array}$ & $\begin{array}{l}\text { Serum } \\
\text { clarith. } \\
\mathrm{mg} \cdot l^{-1}\end{array}$ & $\begin{array}{l}\text { Serum } \\
\text { 14-hydrox. } \\
\text { mg } \cdot l^{-1}\end{array}$ & $\begin{array}{l}\text { Biopsy } \\
\text { clarith. } \\
\mathrm{mg} \cdot \mathrm{kg}^{-1}\end{array}$ & $\begin{array}{c}\text { Biopsy } \\
\text { 14-hydrox. } \\
\text { mg.kg-1 }\end{array}$ & $\begin{array}{l}\text { ELF } \\
\text { clarith. }+ \\
\mathrm{mg} \cdot l^{-1}\end{array}$ & $\begin{array}{l}\text { ELF } \\
\text { 14-hydrox. } \\
\mathrm{mg} \cdot l^{-1}\end{array}$ & $\begin{array}{l}\text { Macro } \\
\text { clarith } \\
\mathrm{mg} \cdot l^{-1}\end{array}$ & $\begin{array}{c}\text { Macro } \\
\text { 14-hydrox. } \\
\text { mg. } l^{-1}\end{array}$ \\
\hline 1 & 4.32 & 3.58 & 0.901 & 23.7 & 4.59 & * & $*$ & 533.2 & 46.4 \\
\hline 2 & 5.23 & 2.69 & 1.05 & 13.4 & 3.71 & $*$ & $*$ & 679.1 & 80.5 \\
\hline 3 & 4.28 & 1.62 & 0.31 & 6.46 & 2.4 & 8.08 & INT & 407.0 & INT \\
\hline 4 & 3.5 & 2.23 & 0.17 & 7.43 & 1.01 & 15.15 & 3.39 & 338.9 & 44.2 \\
\hline 5 & 5.15 & 2.55 & 0.23 & 8.86 & 1.62 & 19.34 & INT & 315.0 & 29.1 \\
\hline 6 & 4.5 & 0.97 & 0.28 & 4.55 & 2.03 & 8.55 & 1.51 & 126.3 & 20.5 \\
\hline 7 & 5.5 & 2.45 & 0.39 & 6.83 & 1.18 & 0.67 & 0.04 & 203.9 & 19.5 \\
\hline 8 & 3.77 & 11.3 & 1.39 & 38.5 & 3.01 & 51.3 & 1.6 & 503.0 & 33.6 \\
\hline 9 & 3.33 & 1.6 & 0.38 & 7.76 & 1.22 & 12.2 & 0.6 & 248.2 & 35.1 \\
\hline 10 & 2.95 & 10.6 & 1.74 & 50.1 & 5.86 & 48.4 & 4.3 & - & - \\
\hline Mean & 4.25 & 3.96 & 0.68 & 16.76 & 2.66 & 20.46 & 1.90 & 372.7 & 38.61 \\
\hline SEM & 0.27 & 1.19 & 0.17 & 4.98 & 0.51 & 6.70 & 0.67 & 58.6 & 6.90 \\
\hline
\end{tabular}

*: lavage not sent for assay; INT: interfering peak on HPLVC: Pt: patient; -: insufficient sample; ELF: epithelial lining fluid; clarith: clarithromycin; 14-hydrox: 14-hydroxy metabolite; Macro: macrophage; HPLC: high performance liquid chromatography.

The assay was validated for plasma/serum and water. Linearity was checked and proven from $0.1 \mu \mathrm{g} \cdot \mathrm{ml}^{-1}$ $(r>0.9996$ for Clari, and $r>0.997$ for $\mathrm{ClaOH})$. The limit of quantification was $50 \mathrm{ng} \cdot \mathrm{ml}^{-1}$, the limit of detection (signal to noise ratio $3: 1$ ) was $400 \mathrm{pg}$ (Clari and $\mathrm{ClaOH}$ ) and $600 \mathrm{pg}$ for Roxi. The recovery of the analytes was $70-90 \%$, the mean recovery was 87,67 and $76 \%$ from serum, for Clari, $\mathrm{ClaOH}$ and Roxi respectively, and 87,87 and $95 \%$ from water/bronchial lavage, respectively. Quality control was performed by assaying spiked samples with each run. The precision was $4-5 \%$ for Clari (conc. $0.26-4.2 \mu \mathrm{g} \cdot \mathrm{ml}^{-1}$ ) and 6-10\% for $\mathrm{ClaOH}$ (conc. 0.11-1.8 $\mu \mathrm{g} \cdot \mathrm{ml}^{-1}$ ).

\section{Results}

Table 1 shows the individual results of the clarithromycin and the 14-hydroxy metabolite in serum bronchial mucosa, epithelial lining fluid and alveolar cells. Concentration of clarithromycin and the 14hydroxy metabolite occurred in bronchial biopsies, epithelial lining fluid and alveolar macrophages, when compared to simultaneous serum levels. The ratio of clarithromycin to 14-hydroxy metabolite was around $6: 1$ in serum and also in bronchial mucosa, but in the ELF was 15:1 and alveolar cells 9.6. Table 2 shows the ratio of clarithromycin to 14-hydroxy metabolite at each site. The ratio is similar in serum and bronchial biopsies but higher in ELF and alveolar cells. In two patients interference occurred in the HPLC measurements due to lignocaine contamination of the lavaged specimens.

Table 2. - Ratios of clarithromycin to 14-hydroxy metabolite

\begin{tabular}{lccrc}
\hline & Serum & $\begin{array}{c}\text { Bronchial } \\
\text { biopsy }\end{array}$ & ELF & $\begin{array}{c}\text { Alveolar } \\
\text { cells }\end{array}$ \\
\hline Mean & 6.41 & 6.00 & 15.09 & 9.63 \\
SD & 3.42 & 3.09 & 10.35 & 2.88 \\
SEM & 1.08 & 0.98 & 4.23 & 1.02 \\
\hline
\end{tabular}

ELF: epithelial lining fluid.

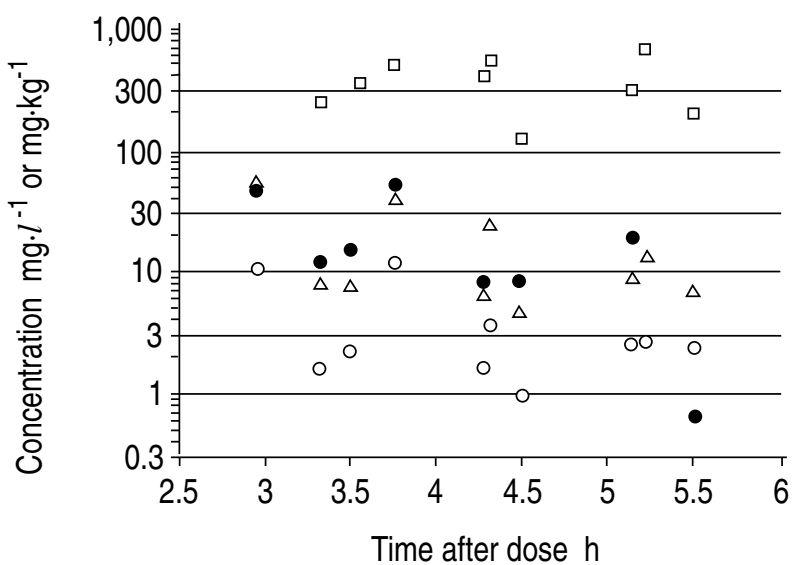

Fig. 1. - Concentrations of clarithromycin at different sites according to time after last dose. $\square$ : alveolar cell clarithromycin $\left(\mathrm{mg} \cdot \mathrm{l}^{-1}\right)$; O: serum clarithromycin $\left(\mathrm{mg} \cdot l^{-1}\right) ; \Delta$ : biopsy clarithromycin $\left(\mathrm{mg} \cdot l^{-1}\right)$; : epithelial lining fluid clarithromycin $\left(\mathrm{mg} \cdot l^{-1}\right)$.

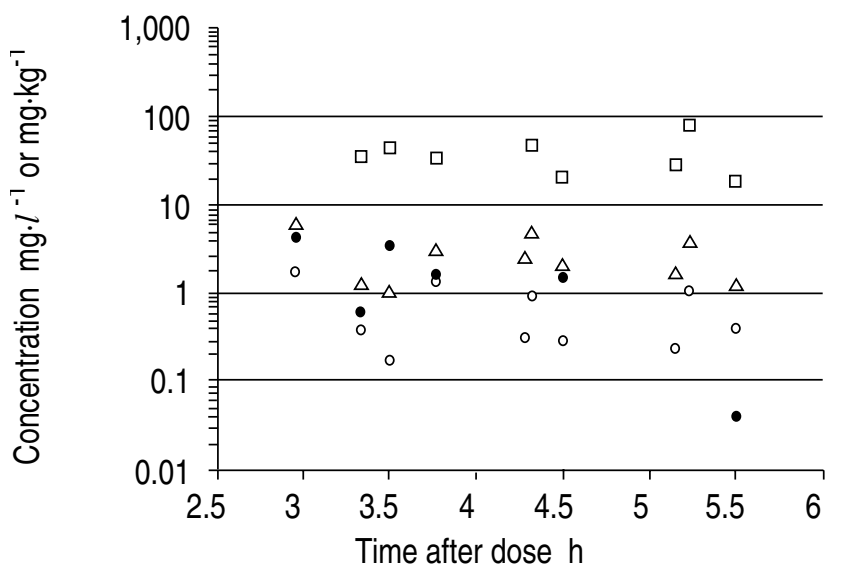

Fig. 2. - Concentrations of 14-hydroxy clarithromycin at different sites according to time after last dose. $\square$ : alveolar cell 14-hydroxy clarithromycin $\left(\mathrm{mg} \cdot \mathrm{l}^{-1}\right)$; $\mathrm{O}$ : serum 14-hydroxy clarithromycin $\left(\mathrm{mg} \cdot \mathrm{l}^{-1}\right)$; $\Delta$ : biopsy 14-hydroxy clarithromycin $\left(\mathrm{mg} \cdot \mathrm{kg}^{-1}\right)$; 0 : epithelial lining fluid 14-hydroxy clarithromycin $\left(\mathrm{mg} \cdot l^{-1}\right)$. 
In two patients, insufficient lavage fluid supernatant was available for ELF calculation, and in one patient insufficient quantity of cell pellet was available for measurement of alveolar cell levels. The mean volume of aspirate from the lavage procedure was $47.3 \mathrm{ml}$ (SD 10.0), and the mean apparent volume of ELF using the urea technique was $14.2 \mu \mathrm{l}$.

Figure 1 illustrates the spread of the clarithromycin concentrations in the four sites according to time after last dose, and figure 2 shows the 14-hydroxy levels. Both figures show that a steady state of drug concentration had been reached after the seven doses of clarithromycin.

\section{Discussion}

We found clarithromycin and the 14-hydroxy metabolite to be concentrated in bronchial biopsies, ELF and alveolar cells compared to serum levels. In one earlier study [8], the concentration of clarithromycin reached a peak in various tissues, including whole lung, $4 \mathrm{~h}$ after oral administration of $500 \mathrm{mg}$ b.i.d. for 3 days. Our mean serum level of $4.0 \mathrm{mg} \cdot \mathrm{l}^{-1}$ was slightly higher than their mean serum level of $2.5 \mathrm{mg} \cdot \mathrm{l}^{-1}$. Steady-state serum levels occurred after five doses of clarithromycin [9]. Following clarithromycin, $500 \mathrm{mg}$ b.i.d. for up to 3.5 days in healthy volunteers, mean plasma ranges for clarithromycin were $2.4-3.5 \mathrm{mg} \cdot l^{-1}$ and for $14-\mathrm{OH}$ were $0.7-0.8 \mathrm{mg} \cdot l^{-1}[10,11]$, values very similar to our own.

This study has found high levels of clarithromycin and 14-OH in bronchial mucosal tissue, and similar levels in ELF. The urea method [6] for measuring ELF volume suffers from net movement of solute from pulmonary capilaries into the alveolar space, resulting in an underestimation of drug concentration. Other techniques for measuring ELF volume have technical difficulties, e.g. blood contamination caused by trauma [12]. More accurate techniques of ELF volume measurement are being developed [13]. Extremely high levels of both clarithromycin and 14-OH were thus found in alveolar cells. Like other macrolides, clarithromycin has been found to be highly concentrated in human polymorphonuclear leucocytes [5, 14], but little information is available about human alveolar macrophages. At all sites studied a steady-state has been reached after the seven doses of clarithromycin. The ratio of clarithromycin to $14-\mathrm{OH}$ was found to be similar in the bronchial biopsies compared to serum, but higher in the ELF and alveolar cells, suggesting differing abilities of the two molecules in penetrating to these sites, or perhaps a different rate of clearance.

Macrolides are lipid soluble and have a low degree of ionization, and hence have good tissue penetration [15]. Clarithromycin has been shown to achieve higher levels than erythromycin in the lungs of rodents [4]. Azithromycin [16] has also been found to be concentrated in lung tissues. Roxithromycin, however, is not concentrated in lung tissues to the same extent [8]. One study in humans showed levels of clarithromycin of $17.5 \mathrm{mg} \cdot \mathrm{kg}^{-1}$ in whole lung tissue with a serum level of $2.6 \mathrm{mg} \cdot \mathrm{l}$, but the study used a bioassay which would not have differentiated between parent compound or 14-OH metabolite [18]. The major and most microbiologically active metabolite is 14-hydroxy-clarithromycin [17]. Hydration of clarithromycin produces stereo-isomers 14-(R) and 14(S). The epimer with the higher antibacterial effect is the 14-(R) form, which is also the main circulating epimer. The process of 14-hydroxylation is dose-dependent [18].

The levels of clarithromycin in the various potential sites of pulmonary infection can be compared to reported in vitro activity. The minimal $50 \%$ and $90 \%$ inhibitory concentration $\left(\mathrm{MIC}_{90}\right)$ of clarithromycin and 14-hydroxy-clarithromycin are shown in Table 3. The $\mathrm{MIC}_{50}$ of clarithromycin and 14-hydroxy-clarithromycin to Streptococcus pneumoniae are both reported to be $0.12 \mathrm{mg} \cdot l^{-1}$; although some relatively resistant organisms have been found, with one study reporting a $\mathrm{MIC}_{90}$ of $16 \mathrm{mg} \cdot l^{-1}$ [19]. However, other workers have found the $\mathrm{MIC}_{90}$ to be as low as $0.015 \mathrm{mg} \cdot \mathrm{l}^{-1}$ [20, 21]. Our study used the relatively high dose of 500 $\mathrm{mg}$ b.i.d., which may be chosen for more severe infections. The bronchial biopsy levels (mean $16.8 \mathrm{mg} \cdot \mathrm{kg}^{-1}$ ) of clarithromycin are, in general, likely to be adequate in the context of bronchitis, although the 14-OH biopsy level is less impressive. Similarly, the mean ELF concentration of clarithromycin of $20.5 \mathrm{mg} \cdot \mathrm{l}^{-1}$ suggests good efficacy against the pneumococcus in pneumonia, although the 14-OH level is much lower. Our subjects did not have active infection including either pneumonia or bronchitis, so the levels found may not necessarily be the same in the presence of such infection. Clarithromycin and 14-OH clarithromycin have both been shown to be independently effective against pneumococcal infection in a mouse model, and significantly more effective than erythromycin [22].

Levels of clarithromycin and $14-\mathrm{OH}$ are likely to be adequate at all sites against Moraxella catarrhalis $\left(\mathrm{MIC}_{90} 0.06 \mathrm{mg} \cdot \mathrm{l}^{-1}\right)$. Poor activity against Haemophilus influenzae has been a major drawback in using erythromycin. In a murine model of $H$. influenzae infection, the 14-OH-clarithromycin metabolite was found to be effective [23]. Some workers have suggested in vitro synergy of clarithromycin and 14-OH-clarithromycin against $H$. influenzae $[3,24)$, although the relatively low levels of 14-OH in ELF and mucosa in our study may not support this occurrence in vivo. The low $\mathrm{MIC}_{90}(0.03$

Table 3. - In vitro susceptibility to clarithromycin and the 14-hydroxy metabolite $\left(\mathrm{mg} \cdot l^{-1}\right)$

\begin{tabular}{lll}
\hline & $\mathrm{MIC}_{50}$ & $\mathrm{MIC}_{90}$ \\
\hline $\begin{array}{l}\text { S. pneumoniae } \\
\text { Clarithromycin }\end{array}$ & $0.02-0.12$ & $0.02-16$ \\
14-hydroxy & $0.02-0.12$ & $0.02-16$ \\
H. influenzae & & \\
Clarithromycin & 4 & 8 \\
14-hydroxy & 4 & 4 \\
M. catarrhalis & & \\
Clarithromycin & 0.06 & 0.06 \\
14-hydroxy & 0.06 & 0.12 \\
\hline
\end{tabular}

Taken from [19-21]. $\mathrm{MIC}_{50}, \mathrm{MIC}_{90}$ : minimal 50\%/90\% inhibitory concentration. 
$\left.\mathrm{mg} \cdot l^{-1}\right)$ of clarithromycin against Mycoplasma pneumoniae [25] and against Legionella pneumophila $\left(\mathrm{MIC}_{90}\right.$, $\left.0.12 \mathrm{mg} \cdot l^{-1}\right)[26]$ suggest high efficacy in these atypical pneumonias. Initial clinical studies in severe Legionella pneumophila infection have been favourable [27]. Clarithromycin was also found to be highly active against Chlamydia pneumoniae [28].

Activity of clarithromycin against Mycobacterium avium complex (MAC) inside mouse cells and human alveolar macrophages has been reported, and was greater than erythromycin [29]. Improved efficacy of clarithromycin has been reported against MAC when combined with ethambutol and rifampicin [30]. The latter study incubated macrophages in a clarithromycin concentration of $2 \mathrm{mg} \cdot l^{-1}$, i.e. slightly below the mean serum level in our study. The extremely high levels of clarithromycin and 14-OH-clarithromycin within human alveolar cells in our study suggest its use in MAC. Clinical studies of clarithromycin in MAC have shown efficacy [31].

Ultimately, evidence of efficacy in respiratory infection relies on clinical studies. A significantly higher clinical cure rate for clarithromycin compared to erythromycin stearate has been reported in communityacquired pneumonia (CAP), with a lower rate of adverse effects in the clarithromycin group [32]. A high clinical cure rate for clarithromycin used in acute bacterial exacerbations of chronic bronchitis has also been reported [33]. We conclude that there is considerable concentration of both clarithromycin and its 14-hydroxy metabolite in alveolar cells, and to lesser extent in ELF and bronchial tissue.

\section{References}

1. Hardy DJ, Guay DRP, Jones RN. Clarithromycin, a unique macrolide: a pharmacokinetic, microbiological and clinical overview. Diagn Microbiol Infect Dis 1992; 15: 39-53.

2. Fernandes PB, Hardy DJ, Bailer R, et al. Susceptibility testing of macrolide antibiotics against Haemophilus influenzae and correlation of in vitro results with in vivo efficacy in a mouse septicaemia model. Antimicrob Agents Chemother 1987; 36: 1243-1250.

3. Hardy DJ, Swanson RN, Rode RA, Marsh K, Shipkowitz $\mathrm{N}$, Clement JJ. Enhancement of the in vitro and in vivo activities of clarithromycin against Haemophilus influenzae by 14-hydroxy-clarithromycin, its major metabolite in humans. Antimicrob Agents Chemother 1990; 34: 1407-1413.

4. Kohno Y, Yoshida H, Suwa T, Suga T. Comparative pharmacokinetics of clarithromycin (TE-031), a new macrolide antibiotic, and erythromycin in rats. Antimicrob Agents Chemother 1989; 33: 751-756.

5. Ishiguro M, Koga H, Kohno S, Hayashi T, Yamaguchi K, Hirota M. Penetration of macrolides into human polymorphonuclear leucocytes. J Antimicrob Chemother 1989; 24: 719-729.

6. Rennard SI Basset G, Lecossier D, et al. Estimation of volume of epithelial lining fluid recovered by lavage using urea as marker of dilution. J Appl Physiol 1986; 60: 532-538.

7. Baldwin DR, Honeybourne D, Wise R. Pulmonary dis- position of antimicrobial agents: methodological considerations. Antimicrob Agents Chemother 1992; 36: 1171-1175.

8. Fraschini F, Scaglione F, Pintucci G, Maccarinelli G, Dugnani S, Demartin G. The diffusion of clarithromycin and roxithromycin into nasal mucosa, tonsil and lung in humans. J Antimicrob Chemother 1991; 27 (Suppl. A.): $61-65$.

9. Peters DH, Clissold SP. Clarithromycin - a review of its antibiotic activity, pharmacokinetic properties and therapeutic potential. Drugs 1992; 44: 117-164.

10. Chu SY, Sennollo LT, Sonders RC. Simultaneous determination of clarithromycin and 14 (R)-hydroxyclarithromycin in plasma and urine using high performance liquid chromatography with electrochemical detection. J Chromatog 1991; 571: 199-208.

11. Gu JW, Scully BE, Neu HC. Bacterial activity of clarithromycin and its 14-hydroxy metabolite against Haemophilus influenzae and streptococcal pathogens. J Clin Pharmacol 1991; 31: 1146-1150.

12. Baldwin DR, Wise R, Andrews JM, Honeybourne D. Microlavage: a technique for determining the volume of epithelial lining fluid. Thorax 1991; 46: 658662.

13. Peterson BT, Griffith DE, Tate RW, Clancy SJ. Singlecycle bronchoalveolar lavage to determine solute concentrations in epithelial lining fluid. Am Rev Respir Dis 1993; 147: 1216-1222.

14. Anderson $\mathrm{R}$, Joone $\mathrm{G}$, Van Rensburg CEJ. An in vitro evaluation of the cellular uptake and intraphagocytic bioactivity of clarithromycin, a new macrolide antimicrobial agent. J Antimicrob Chemother 1988; 22: 923-933.

15. Woolmer F, Pride NB, Rhodes CG, et al. Measurement of pulmonary erythromycin concentration in patients with lobar pneumonia by means of positron tomography. Lancet 1982; ii: 1361-1364.

16. Baldwin DR, Wise R, Andrews JM, Ashby JA, Honeybourne D. Azithromycin levels at the sites of pulmonary infection. Eur Respir J 1990; 3: 886-890.

17. Ferrero JL, Bopp BA, Marsh KC, Quigley SC, Johnson MJ. Metabolism and disposition of clarithromycin in man. Drug Metab Disp 1990; 18: 441-446.

18. Davey PG. The pharmacokinetics of clarithromycin and its 13-OH metabolite. J Hosp Infect 1991; 19 (Suppl. A): $29-37$.

19. Logan MN, Ashby JP, Andrews JM, Wise R. The in vitro and disc susceptibility of clarithromycin and its 14-hydroxy metabolite. J Antimicrob Chemother 1991; 27: $161-170$.

20. Jansson L, Kalin M. Comparative in vitro activity of A56268 against respiratory tract pathogens. Eur J Clin Microbiol 1987; 6: 494-496.

21. Hardy DJ, Hensey DM, Beyer JM, Vojtka C, McDonald EJ, Fernandes PB. Comparative in vitro activities of new 14-, 15- and 16-membered macrolides. Antimicrob Agents Chemother 1988; 32: 1710-1719.

22. Bedos JP, Azoulay-Dupuis E, Vallee E, Verber B, Pocidalo JJ. Individual efficacy of clarithromycin (A-56268) and its major human metabolite 14-hydroxy-clarithromycin (A-62671) in experimental pneumococcal pneumonia in the mouse. J Antimicrob Chemother 1992; 29: 677-685.

23. Vallee E, Azoulay-Dupuis E, Swanson R, BergogneBérézin E, Pocidalo J-J. Individual and combined activities of clarithromycin and its 14-hydroxy metabolite in a murine model of Haemophilus influenzae infection. $J$ Antimicrob Chemother 1991; 27 (Suppl. A): 31-41. 
24. Dabernat H, Delmas C, Seguy M, Fourtillan JB, Girault J, Lareng ME. The activity of clarithromycin and its 14hydroxy metabolite against Haemophilus influenzae determined by in vitro and serum bactericidal test. J Antimicrob Chemother 1991; 27 (Suppl. A): 19-30.

25. Waites KB, Cassell GH, Canupp KC, Fernandes PB. In vitro susceptibilities of mycoplasmas and ureaplasmas to new macrolides and aryl-fluorquinolones. Antimicrob Agents Chemother 1988; 32: 1500-1502.

26. Liebers DM, Baltch AL, Smith RP, Hammer MC, Conroy JV. Susceptibility of Legionella pneumophilia to eight antimicrobial agents including four macrolides under different assay conditions. J Antimicrob Chemother 1989; 23: $37-41$.

27. Hamedani P, Ali J, Hafeez S, et al. The safety and efficacy of clarithromycin in patients with Legionella pneumonia. Chest 1991; 100: 1503-1506.

28. Chirgwin K, Roblin PM, Hammerschlag MR. In vitro susceptibilities of Chlamydia pneumoniae (Chlamydia spp. strain TWAR). Antimicrob Agents Chemother 1989; 33: $1634-1635$.

29. Yajko DM, Nassos PS, Sanders CA, Gonzalez PC, Hadley WK. Comparison of the intracellular activities of clar- ithromycin and erythromycin against Mycobacterium avium complex strains in $\mathrm{J} 774$ cells and in alveolar macrophages from human immunodeficiency virus type 1-infected individuals. Antimicrob Agents Chemother 1992; 36: 1163-1165.

30. Rastogi N, Labrousse V. Extracellular and intracellular activities of clarithromycin used alone and in association with ethambutol and rifampin against Mycobacterium avium complex. Antimicrob Agents Chemother 1991; 35: 462-470.

31. Dautzenberg B, Truffots C, Legris S, Meyohas M-C, Berlie HC. Activity of clarithromycin against Mycobacterium avium infection in patients with the acquired immune deficiency syndrome. Am Rev Respir Dis 1991; 144: 564-569.

32. Anderson G, Esmonde JS, Coles S, Macklin J, Carnegie C. A comparative safety and efficacy study of clarithromycin and erythromycin steorate in communityacquired pneumonia. J Antimicrob Chemother 1991; 27 (Suppl. A): 117-124.

33. Aldons PM. A comparison of clarithromycin with ampicillin in the treatment of outpatients with acute bacterial exacerbations of chronic bronchitis. J Antimicrob Chemother 1991; 27 (Suppl. A): 101-108. 